\title{
SUBSIDENCE HAZARDS IN DIFFERENT TYPES OF KARST: EVOLUTIONARY AND SPELEOGENETIC APPROACH
}

\author{
Alexander KLIMCHOUK
}

\begin{abstract}
The typology of karst, based on distinguishing the successive stages of general hydrogeological evolution, between which major boundary conditions and the overall circulation pattern change considerably, gives a natural clue, properly to classify and tie together karst breakdown settings, speleogenetic styles and breakdown development mechanisms. Subsidence hazards vary substantially between the different karst types, so that classifying individual karst according to typology can provide an integrated general assessment. This provides a useful basis for selection and realization of region- and site-specific assessment schemes and management strategies.

Intrastratal karst types, subjacent karst in particular, are most potent in generating subsidence problems. Exposed karst types, especially open karst, are the least likely to pose subsidence hazard problems, despite them being recognized more obviously as karstic areas.
\end{abstract}

KEYWORDS: karst types, karst subsidence hazard assessment, karst breakdown mechanisms

\section{Introduction}

The term "karst subsidence" refers to the surface features resulting from more or less long acting destructive processes, hidden in the subsurface, which precede the appearance of surface landforms. When addressing subsidence origin, mechanisms and (eventually) prediction, it is common to refer, explicitly or implicitly, to this preceding hidden development. It is therefore convenient to use the more general concept of "karst breakdown" to denote the totality of processes and phenomena of gravitational and/or hydrodynamic destruction of the ceiling of a karst cavity and of the overlying sediments.

There can be many different approaches to karst subsidence hazard assessment, depending on scale (from regional to site-specific), natural settings and practical purposes. However, for general regional assessment it is desirable to develop a more unified integrated approach that would result in a basis for selection of region- or site-specific assessment schemes and management strategies. This paper is an attempt to outline such an approach, based on the evolutionary typology of karst. Though this approach seems to be quite promising for karst subsidence hazard assessment in both carbonates and sulphates, this paper places special emphasis upon 
gypsum karst.

Karst typology, based on distinguishing successive stages of general hydrogeological evolution, between which major boundary conditions and the overall circulation pattern change considerably, seems to give a natural clue to classify and tie together karst subsidence settings, speleogenetic styles and breakdown development mechanisms.

\section{The evolutionary typology of karst}

An evolutionary approach to the typology of karst has been elaborated by Klimchouk (1996) and Klimchouk and Ford (2000). It incorporates some earlier ideas on differentiation between karst types suggested by Ivanov (1956), Quinlan (1978) and others. Types of karst are viewed as successive stages of hydrogeological evolution, between which the major boundary conditions, the overall circulation pattern and extrinsic factors and intrinsic mechanisms of karst development appear to change considerably (Fig.1). The different types of karst are marked by characteristic styles of karst system development, which result from certain regular combinations of:

a) structural prerequisites for groundwater flow and speleogenesis;

b) flow regimes;

c) recharge modes and recharge/discharge configurations;

d) groundwater chemistry;

e) degree of speleogenetic inheritance from earlier conditions.

The evolutionary sequence of karst types is also linked to the relationships with insoluble cover beds, the very important factor of the breakdown development. Consequently, it makes a convenient basis to view breakdown mechanisms and assess subsidence hazards on a regional scale.

Fig.1 outlines the entire sequence of karst settings (stages) that a given formation could experience during its history. In actuality no known individual karst displays all of the possible sequence, but many have experienced several of the stages. The karst may be destroyed completely, along with its host formation, within the same stage that its development commenced. This is more common for karst in sulphates than in carbonates and is the fate of most salt karsts. On the opposite extreme, carbonate karst can survive through several burial-exposure cycles, being repeatedly fossilised and rejuvenated.

Syngenetic karst in evaporites, if it develops at all, is embryonic, limited in extension and does not present appreciable engineering problems. More commonly, freshly deposited sediments are buried without suffering significant earlier dissolution. Karstification may be initiated at any of the stages of intrastratal development or delayed until stripping of the cover exposes the rock.

Intrastratal karst is considered to develop within rocks already buried by younger strata, where karstification is later than deposition of the cover rocks. Hydraulic and hydrochemical conditions are shown to be quite potent for the development of deep- 


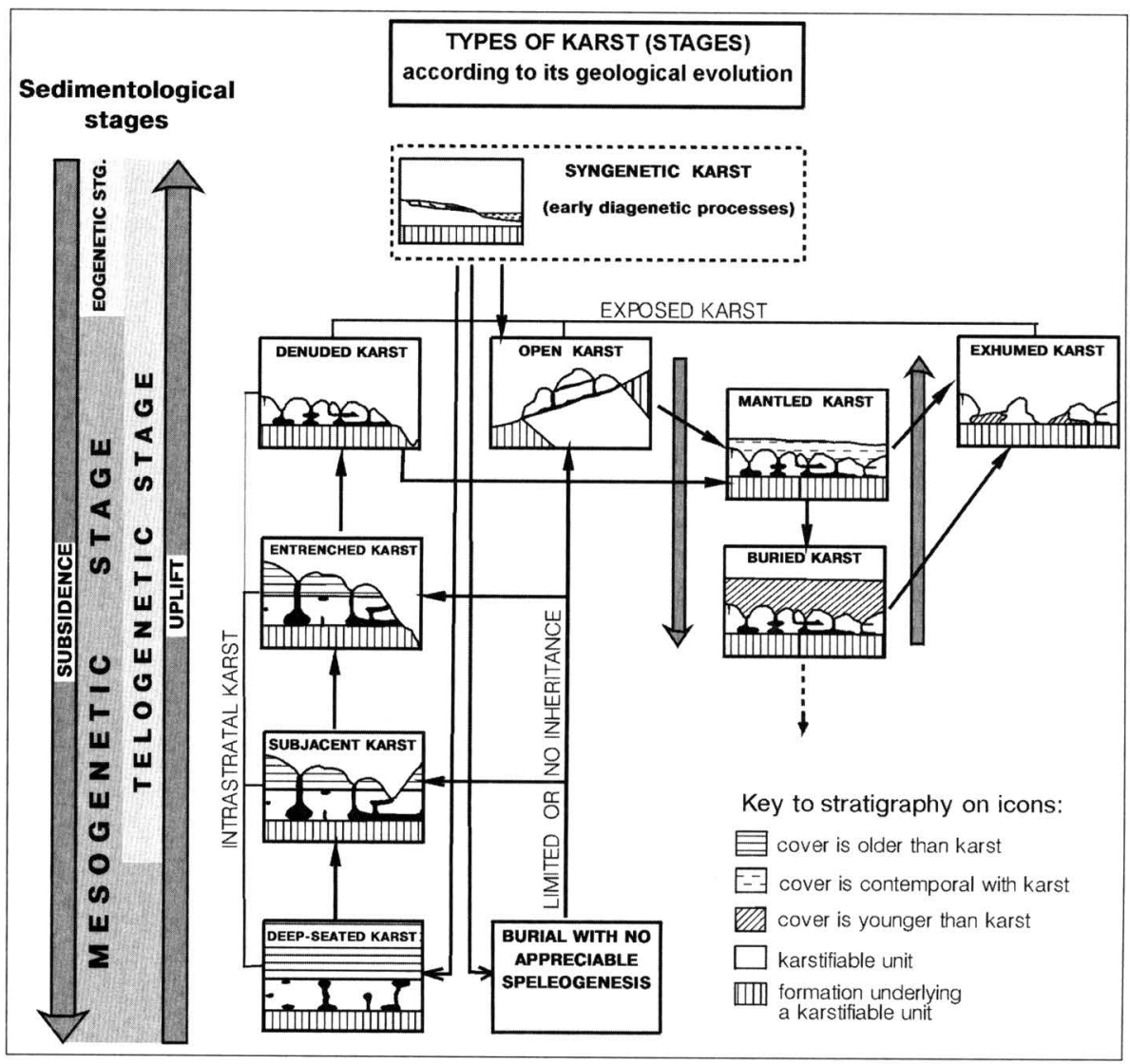

Fig.1. - Evolutionary types of karst (from Klimchouk and Ford, 2000).

seated karst in many situations, particularly when soluble beds are sandwiched between insoluble but pervious formations and where vertical cross-formational hydraulic communication is favoured (Klimchouk, 1997a, 2000a). As a consequence of standard denudation and uplift on the continents, the deep-seated rocks are shifted with time into progressively shallower positions. At some stage en route to the surface, erosional incision into the cover rocks locally breaches the hydrogeological confinement and the aquifer is brought into direct hydraulic connection with the surface (subjacent karst). Further incision causes inversion of the circulation system, drastic changes in recharge-discharge configuration and establishment of vadose zone and water table conditions within the karstic strata (entrenched karst). At this point some insoluble beds still commonly cap the unit over most of its area. Progressive denudation may eventually expose the rock entirely (denuded karst, which also falls into the category of exposed karst types).

The boundaries between the above types are transitional in reality but can be drawn in the following way. Deep-seated karst is not evident at the surface and the soluble 
rock is not exposed. Subjacent karst occurs where the soluble rock is locally breached by erosion over a minor part of its thickness, and karst features may already be expressed at the surface as springs and/or collapse and subsidence features. Entrenched karst is where the entire thickness of the soluble rock is entrenched along valleys, but the insoluble cap remains over most of the interfluves. Denuded karst is where the cap rocks are removed. Where there is continuous karst development from the deep-seated stage to the denuded stage the role of inheritance can be quite important.

The different intrastratal karst stages are marked by characteristic changes in the geological controls of speleogenesis, in the dynamics of the flow system, recharge mode and recharge/discharge configurations and in the groundwater chemistry. Confined circulation systems, inherent in deep-seated karst, remain dominant although progressively diminishing through the subjacent stage. Confined systems then give way to unconfined phreatic flow when passing to the entrenched and exposed stages, with consequent development of water-table and vadose zones. The mode of recharge to a given karst unit (which to a great extent determines the style of speleogenesis) tends to switch from predominantly diffuse and steady flow from the adjacent formations in deep-seated karst, to highly focused and variable flow from the surface in subjacent and entrenched karsts where caprocks are poorly permeable. However, the occurrence of diffusely permeable caprocks may still maintain diffuse recharge in these settings. Recharge becomes less focused and variable in denuded karst, but underground flow patterns are largely inherited from the earlier stages.

Open and denuded karst types (soluble rocks exposed at the surface) are characterized by similarly exposed geomorphic settings, but differ in their previous karstification history. Whereas denuded karst is former intrastratal karst, open karst represents the "pure line" of exposed development. That is, karst evolved solely when the soluble rock has been exposed to the surface, with either limited or no inheritance.

Mantled karst is karst covered by significant thicknesses of unconsolidated sediments, which accumulate as the karst develops. Most common are soils formed from the insoluble residuum of impure limestones and dolostones (locally-derived or "autochthonous" deposits). Mantled karst should be distinguished from buried karst, which is a complete infilling and burial by later materials such as transgressive marine sediments, reducing or (usually) terminating the karstification. Buried karst should not be confused with intrastratal karst, where the karstic rocks were buried before any karstification occurred. "Buried karst" has the simple direct meaning that a karst was exposed and then buried. When karst is buried, it is generally fossilized, and so represents the most unambiguous case of true palaeokarst.

\section{Genetic types of caves in gypsum, their relevance to the karst types and potency to generate karst breakdowns}

Cavities play the most fundamental role in karst breakdown processes as they give rise to the development of additional (absent before the onset of speleogenesis) strain in ceiling and overburden materials, thus stimulating ceiling destruction when certain 
critical values are exceeded. In other words, speleogenesis and the presence of dissolutional cavities are the ultimate cause of karst subsidence. Therefore, knowledge of the distribution and characteristics of cavities in a given karst is one of the most important components of subsidence hazard assessment.

In most cases karst breakdown processes develop where the soluble rocks are already karstified to some degree. The importance of contemporary speleogenesis (i.e. in a time-scale that corresponds to the assessment goals) on karst breakdown potential is negligibly low in carbonate karsts but in the case of evaporites it should be taken into account because of the much higher dissolution rates of sulphates and haloids in many natural or antropogenically modified situations. In any case, the existence of cavities, whether inherited from past settings or formed under contemporary settings, is the most important consideration for the assessment of karst breakdown potential.

Caves of different kinds can have different potential to generate breakdowns. It depends not only on their size and the depth of occurrence, but also on their origin, which determines the characteristics of cave patterns and presence of morphogenetic components related to transverse structural or lithological discontinuities in the overburden. Such components, for instance, are shown to be the main breakdowngenerating features in the gypsum karst of the Western Ukraine (see Klimchouk and Andrejchuk, this volume); a rule that probably holds true for any intrastratal karst. Moreover, knowledge of cave origin allows inferrences to be drawn about the relation of cave patterns to specific past or modern geological or geomorphological features. Hence it gives an important clue to subsidence prediction. An example is the characteristic relationship between artesian transverse caves and valleys (palaeo-valleys) partially incised into the confining overburden.

Although comprehensive judgement on cave genesis can be based only on special speleogenetic studies, some preliminary ideas on what kind of caves can be expected in a given karst can be inferred from identifying its type. There is a distinct relationship between genetic types of gypsum caves, speleogenetic settings and the types of karst (Klimchouk, 2000b; see Table). Complications arise from the fact that the sub-types of intrastratal karst, as well as denuded karst (former instrastratal karst) may inherit cave patterns formed during the preceding stages. This makes speleogenetic studies indicative of a karst type and of the evolution of a given karst.

During the deep-seated stage caves are likely to form where gypsum is sandwiched between aquifers or at least underlain by an aquifer. In the former case, depending on the structural pre-requisites present (uniform fissuring or discrete prominent discontinuities), either maze caves (type 1 in the Table) or large discrete voids (type 2) can be formed by transverse flow across the gypsum bed. In the latter case, and also where a thick gypsum sequence, sandwiched between aquifers, is of negligible vertical permeability, large discrete voids can form along the base of the gypsum due to natural convection and removal of dissolved load via the underlying aquifer. Caves of both types can be inherited, though become relict, in the subsequent stages (subjacent, entrenched and denuded), with superimposed development of contemporary caves of types 3 and 4 . 
Table. Genetic classification of caves in gypsum, with relation to karst types and speleogenetic settings

\begin{tabular}{|c|c|c|c|c|}
\hline \multirow{2}{*}{$\begin{array}{l}\text { TYPE OF } \\
\text { KARST }\end{array}$} & \multicolumn{3}{|c|}{ SPELEOGENETIC SETTINGS } & \multirow{2}{*}{$\begin{array}{l}\text { CHARACTERISTICS OF } \\
\text { SOLUTION CAVES }\end{array}$} \\
\hline & $\begin{array}{l}\text { Hydro- } \\
\text { geological } \\
\text { conditions } \\
\text { Principal } \\
\text { Complementary }\end{array}$ & $\begin{array}{l}\text { Initial } \\
\text { permeability } \\
\text { (before speleo- } \\
\text { genesis) }\end{array}$ & $\begin{array}{l}\text { Flow pattern through gypsum } \\
\text { and type of recharge }\end{array}$ & \\
\hline \multirow[t]{2}{*}{$\begin{array}{l}\text { Intrastratal } \\
\text { deep-seated }\end{array}$} & \multirow[t]{3}{*}{$\begin{array}{l}\text { Confined } \\
\text { (artesian) }\end{array}$} & \multirow{3}{*}{$\begin{array}{l}\text { Fairly } \\
\text { homogeneous } \\
\text { generally low } \\
\text { Very hetero- } \\
\text { geneous, } \\
\text { generally low to } \\
\text { negligible, } \\
\text { locally high }\end{array}$} & \multirow{3}{*}{$\begin{array}{l}\text { Ascending transverse flow across } \\
\text { gypsum unit sandwiched between } \\
\text { aquiferous beds, with possible } \\
\text { lateral component; } \\
\text { dispersed basal recharge } \\
\text { Ascending transverse flow; } \\
\text { localized basal recharge } \\
\text { Lateral flow in the underlying } \\
\text { aquifer, natural convection "cells" } \\
\text { in gypsum }\end{array}$} & $\begin{array}{l}\text { 1. Rectilinear 2-D or 3-D } \\
\text { (multi-storey) mazes }\end{array}$ \\
\hline & & & & \multirow{2}{*}{$\begin{array}{l}\text { 2. Discrete voids, } \\
\text { commonly large and } \\
\text { isometric } \\
\therefore-\end{array}$} \\
\hline \multirow{3}{*}{$\begin{array}{l}\text { Intrastratal } \\
\text { subjacent }\end{array}$} & & & & \\
\hline & \multirow{3}{*}{$\begin{array}{l}\text { confined, } \\
\text { phreatic, } \\
\text { water table, } \\
\text { vadose }\end{array}$} & \multirow{3}{*}{$\begin{array}{l}\text { Heterogeneous: } \\
\text { low to high }\end{array}$} & \multirow{3}{*}{$\begin{array}{l}\text { Ascending flow with possible } \\
\text { considerable lateral component; } \\
\text { localized or dispersed basal } \\
\text { recharge } \\
\text { Descending flow with } \\
\text { considerable lateral component; } \\
\text { localized recharge from coverbeds } \\
\text { and via superficial sink points; } \\
\text { possible backflooding from nearby } \\
\text { rivers }\end{array}$} & $\begin{array}{l}\text { Continuing development of } \\
\text { types } 1 \text { and } 2\end{array}$ \\
\hline & & & & $\begin{array}{l}\text { 3. "Through caves": linear } \\
\text { or crudely dendritic in plan, } \\
\text { horizontal, inclined, or } \\
\text { step-like in profile }\end{array}$ \\
\hline \multirow{4}{*}{$\begin{array}{l}\text { Intrastratal } \\
\text { entrenched }\end{array}$} & & & & $\begin{array}{l}\text { Lateral enlargement of } \\
\text { inherited artesian caves } \\
\text { at the water table }\end{array}$ \\
\hline & \multirow[t]{3}{*}{$\begin{array}{l}\text { phreatic, } \\
\text { water table, } \\
\text { vadose }\end{array}$} & \multirow[t]{3}{*}{$\begin{array}{l}\text { Heterogeneous: } \\
\text { low to high }\end{array}$} & \multirow{3}{*}{$\begin{array}{l}\text { Descending flow with possible } \\
\text { considerable lateral component; } \\
\text { localized recharge from coverbeds } \\
\text { and via superficial sink points; } \\
\text { possible backflooding from nearby } \\
\text { rivers }\end{array}$} & $\begin{array}{l}\text { Continuing or newly started } \\
\text { development of type } 3 \\
\text { caves }\end{array}$ \\
\hline & & & & $\begin{array}{l}\text { 4. Vertical pipes } \\
\text { developing downwards } \\
\text { from the top of the gypsum }\end{array}$ \\
\hline & & & & $\begin{array}{l}\text { Lateral enlargement of } \\
\text { inherited artesian caves at } \\
\text { the water table }\end{array}$ \\
\hline \multirow[t]{3}{*}{$\begin{array}{l}\text { Exposed } \\
\text { denuded }\end{array}$} & \multirow[t]{3}{*}{$\begin{array}{c}\text { phreatic, } \\
\text { water table } \\
\text { vadose }\end{array}$} & \multirow[t]{3}{*}{$\begin{array}{l}\text { Heterogeneous: } \\
\text { generally high }\end{array}$} & \multirow{3}{*}{$\begin{array}{l}\text { Descending flow with possible } \\
\text { considerable lateral component; } \\
\text { localized recharge via superficial } \\
\text { sink points; possible backflooding } \\
\text { from nearby rivers }\end{array}$} & $\begin{array}{l}\text { Continuing or newly started } \\
\text { development of type } 3 \\
\text { caves }\end{array}$ \\
\hline & & & & Vertical pits at sink points \\
\hline & & & & $\begin{array}{l}\text { Lateral enlargement of all } \\
\text { cavities at the water table }\end{array}$ \\
\hline \multirow{3}{*}{$\begin{array}{l}\text { Exposed } \\
\text { open }\end{array}$} & \multirow{3}{*}{$\begin{array}{c}\text { phreatic } \\
\text { water table } \\
\text { vadose }\end{array}$} & \multirow{3}{*}{$\begin{array}{l}\text { Heterogeneous: } \\
\text { generally low }\end{array}$} & \multirow{3}{*}{$\begin{array}{l}\text { Descending flow with possible } \\
\text { considerable lateral component; } \\
\text { localized recharge via superficial } \\
\text { sink points; possible backflooding } \\
\text { from nearby rivers }\end{array}$} & $\begin{array}{l}\text { Development of type } 3 \\
\text { caves }\end{array}$ \\
\hline & & & & Vertical pits at sink points \\
\hline & & & & $\begin{array}{l}\text { Lateral enlargement of all } \\
\text { cavities at the water table }\end{array}$ \\
\hline
\end{tabular}


The most unambiguous case in terms of karst type/cave type relationship, is where a sulphate sequence rests on, or is sandwiched between, impervious formations. This situation excludes the possibility of the formation of artesian caves, both maze and discrete void types. Karstification is unlikely to evolve in the deep-seated stage and speleogenesis during any subsequent stage is limited to types 3 (linear or crudely dendritic "through caves") and 4 (vertical pipes or pits). If karstification commences only during the exposed stage, it results in open karst, where only contemporary caves form in accordance with the present settings.

The potency of caves to generate breakdowns varies between types. In maze cave systems of type 1 the bulk of cave passages present little or no potential for breakdown until shifted to a shallow subsurface position. However, breakdowns can readily initiate from outlet cupolas/domepits, which represent places where water discharged from a cave system to the upper aquifer during the period of transverse artesian speleogenesis (Klimchouk and Andrejchuk, this volume). Caves of type 2 associated with prominent structural discontinuities can generate breakdown structures active enough to propagate through large thicknesses of overburden (Klimchouk and Andrejchuk, 1996). Voids similar in morphology and size but formed solely by "upward" dissolution due to natural convection (not related to cross-formation discontinuities and flow) can remain stable until moved to the shallow subsurface. Linear or crudely dendritic caves of type 3 , genetically associated with unconfined settings, present little potential for breakdown. Vertical "descending" dissolution pipes (type 4) commonly initiate breakdown in the overburden in intrastratal entrenched karsts but genetically similar vertical pits formed in exposed karst settings do not generate any breakdown hazard.

In unconfined gypsum karst, dissolution at the water table is not considered as a separate speleogenetic situation, but it can give rise to considerable modification of caves of any genetic type. Conditions where the water table is positioned within the karstified gypsum can establish in all the karst types except deep-seated karst. In gypsum aquifers that receive constant or periodic aggressive recharge low in TDS, chemical stratification develops due to the density difference between the "fresh" water still low in sulphates and the bulk water enriched in sulphates (Klimchouk, $1997 \mathrm{~b}$ ). Consequently, the water in the uppermost layer (5 to $15 \mathrm{~cm}$ ) of cave lakes ("aquifer windows") generates much higher dissolution rates than water in deeper parts (Klimchouk and Aksem, 2002). This has a pronounced morphological effect, causing the development of horizontal notching and inwardly inclined wall facets in caves of any type that appear to be within the water table fluctuation range. Such lateral enlargement of caves may increase the cross-sectional spans of passages and chambers three to four times, hence drastically decreasing the ceiling stability and increasing the potential for breakdown and subsidence to occur. The most pronounced development at the water table occurs where recharge comes from an underlying aquifer, or from non-karstic surfaces, or as backflooding from a nearby river, i.e. without having much contact with gypsum. Hence, it is most common within subjacent and entrenched karsts. In exposed karsts the above effect is less important. 


\section{Settings of karst breakdown and their relevance to karst types}

Karst breakdown development and subsidence occurrence depend on many conditions and factors, the totality of which can be viewed as a setting for the karst breakdown process in a given karst. For the purposes of general subsidence hazard assessment it is necessary to distinguish typical settings within a tangible classification scheme. In Fig.2 such an attempt is presented, based on the most common combinations of the three categories of conditions and factors that strongly influence the karst breakdown process, namely:

1) Presence and structure of the overburden;

2) Lithological (geotechnical) properties of individual units in the cover;

3) Hydrogeologic conditions (especially piezometric levels and hydraulic gradients).

These categories correlate to the criteria used to distinguish the evolutionary types of karst. It can be seen from Fig. 2 that settings evolve from left to right according to hydrogeological conditions, from confined to unconfined, and from below upward, according to the cover structure, from deep-seated karst with multiple-layer cover, to exposed karst with no cover. Therefore, the evolutionary typology of karst, suggested above as the basis for integrated regional subsidence hazard assessment, contains a useful indication of karst breakdown settings.

The suggested classification also gives room for consideration of breakdown processes and mechanisms.

In the open karst setting (0-U1) and in cases of single-layer cover represented by solid rocks or soft but impervious sediments (I-C1 and I-U1), mainly gravitational processes take part in karst breakdown development.

In settings where loose pervious sediments occur in the cover, a variety of gravitational and hydrodynamic processes can take part in breakdown development, and this overall process commonly consists of a number of stages. The composition of the component processes and stages of breakdown development (i.e. the breakdown mechanism) are determined by the layered structure of the overburden, the permeability and coherence of particular beds, and by hydrogeological conditions. As the proposed classification of breakdown settings includes all these factors, the mechanisms, when adequately revealed, formalised and classified, can be put into a relationship with the specified settings.

In general, beds of permeable loose sediments (i.e. sands) provide a setting wherein processes of hydrodynamic destruction (such as suffosion, liquefaction, erosion, etc.) predominate, whereas low-permeability or fully-drained beds of more coherent sediments or solid rocks promote arching, which supports void stoping and serves as an arena for mainly gravitational destruction. During the course of breakdown propagation through the stratified overburden, some non-equilibrium stages can be followed by quasi-equilibrium stages. The ability of some beds within the overburden to bridge a void is the main pre-requisite for the collapse style of eventual surface deformation (as against gradual subsidence). 


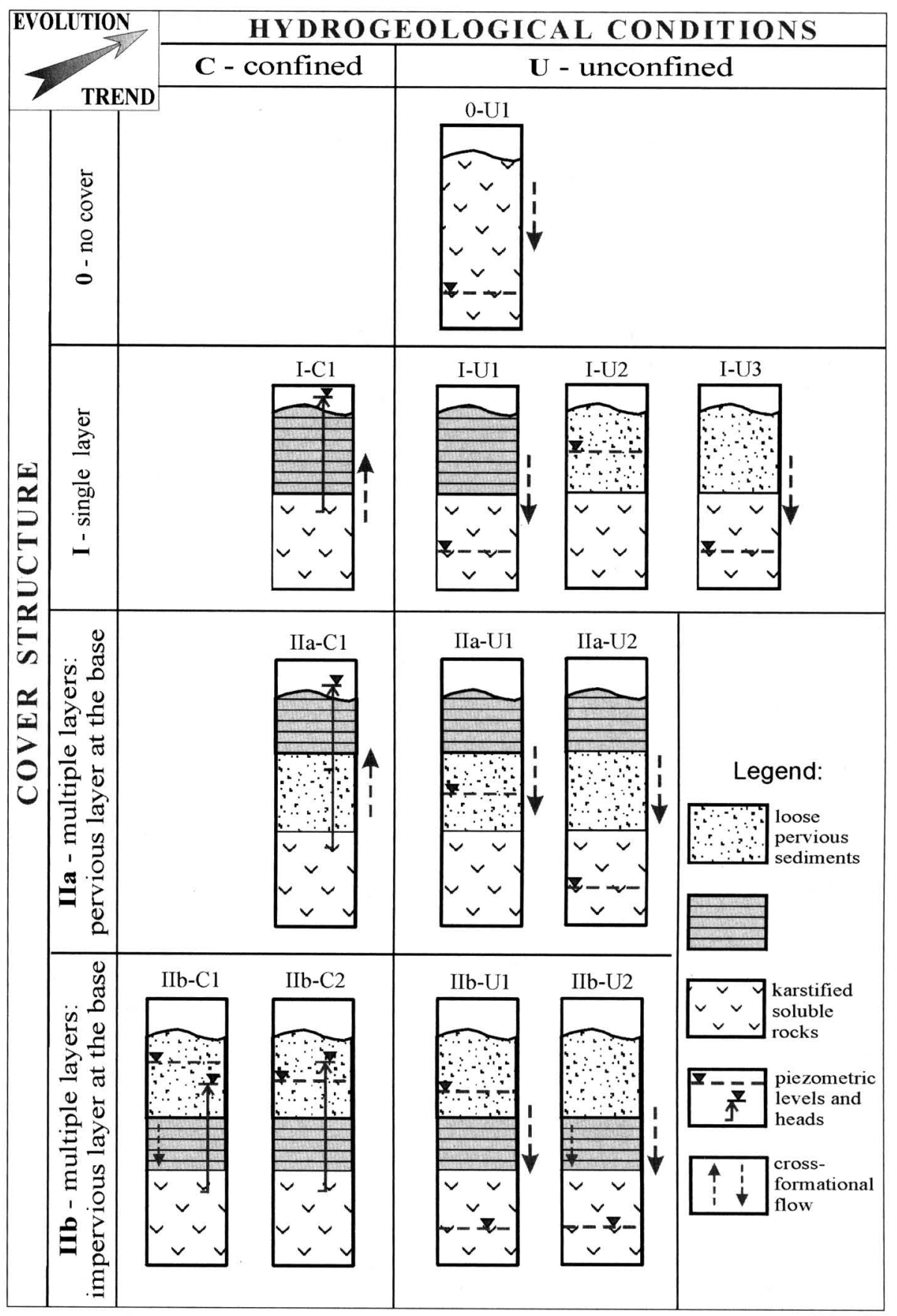

Fig.2. - Classification of karst breakdown settings 


\section{Subsidence hazard in different types of gypsum karst: regional examples}

As shown above, the evolutionary types of karst differ quite naturally in styles of speleogenesis, karst breakdown settings and characteristic breakdown mechanisms. Thus it is natural that subsidence hazards differ substantially between karst types, and that it can be assessed in general by classifying a given individual karst according this typology. A brief appraisal of the each conceptual karst type is given below, with particular regard to their potency to pose subsidence hazards. Representative regional examples are referred to from the extensive review of gypsum karst of the world presented in Klimchouk, Lowe, Cooper and Sauro (1996) and references therein.

If developed at all, syngenetic karsts in evaporites are incipient, limited in extent (as for instance in some modern evaporate basins in the Qinghai-Xizang Plateau, China and in the Caspian region, Turkmenistan) and they do not present any engineering problems. More commonly, freshly deposited sediments are buried without suffering significant earlier dissolution. Where buried, karstification may commence during any of the stages of intrastratal development, or be delayed until stripping of the cover exposes the rock.

Exposed karst areas in evaporitic rocks are commonly rather limited in extent, and despite the fact that they are more obviously recognised as "karst" than is intrastratal karst, they too present only limited or no engineering problems. In open karst, solution dolines that form gradually are overwhelmingly predominant, whereas collapse and subsidence features are rare. This is for two reasons:

Gravitational breakdown mechanism (cave ceiling collapse) dominate in open karst. In general, this mechanism is of much less importance in generating collapse/subsidence features than those involving hydrodynamic destruction and void stoping through the overburden.

Contemporary cave development in open settings favours the formation of linear or crudely dendritic caves of rather small cross-section, which rarely give rise to massive ceiling destruction.

However, collapse and subsidence features may occur more readily in denuded karst, mainly reflecting the large degree of inheritance in underground karstification (much higher overall cave porosity) and the presence of patches of loose material at the top of karstic rocks.

Examples of open kart include Zorbas in South Spain, the Erbo basin in East Spain, the Central Apennines and Sicily in Italy, and some areas in the North Caucasus in Russia. The Gypsum Plain in West Texas and New Mexico, USA, probably falls into the denuded karst category.

Deep-seated intrastratal karst is now considered to be much more widespread than traditionally supposed, although it is, by definition, not evident at the surface. This is either due to the considerable thickness of overburden (which prevents breakdown structures reaching the surface) or because breakdowns have not yet been triggered. However, human impacts may change conditions rapidly (for instance, by 
changing hydrodynamic gradients, flow rates and the circulation pattern by groundwater abstraction) so that breakdown processes are triggered and intensified to cause subsidence at the surface. This makes deep-seated karst settings particularly hazardous, because related areas previously not recognised as karst may present engineering problems that are not expected. The above situation signifies an induced transition from deep-seated to subjacent karst type. Remarkable examples are associated with the open-pit mining of sulphur and clays in the deep-seated karst belt of the Western Ukraine.

Depending on structural pre-requisites, caves forming in deep-seated gypsum karst are either artesian maze systems or large discrete voids. Modern (presently at the artesian stage) maze caves are identified by indirect means in the deep-seated karst belt in the Western Ukraine; relict cave systems are known in (the entrenched karsts of) the Western Ukraine, Ural (Russia), the Madrid basin (Spain) and the Paris basin (France). The most instructive examples of the large discrete cavities are caves of the "schlotten" type in the Zechstein gypsum of the South Harz, Germany (Kempe, 1996). In this region, more than 100 cavities of this type have been intersected by mines, at depths of up to $400 \mathrm{~m}$. They can be very big, up to 40 to $60 \mathrm{~m}$ in cross-section and height.

Subjacent karst is by far the most relevant to the subsidence problem, because it represents a transitional stage during which progressive erosional entrenchment drastically changes the hydrodynamics, from confined through semi-confined to vadose and water-table conditions. These changes are usually accompanied by reduction of the overburden thickness caused by denudation, thus permitting propagation of breakdown features from a soluble unit to the surface. Most karst areas, whether carbonate or evaporite, which demonstrate distinct engineering problems due to subsidence belong to this type. Changes occurring during the subjacent karst stage include well-recognized breakdown-triggering effects (Newton, 1984; White and White, 2000). These effects include decrease of hydraulic heads and removal of buoyant support, increase of hydraulic gradients and flow velocities, base level back-flooding, etc. Most of these accelerate dissolutional enlargement of cavities due to the increase of flow rates, action of back-flooding and vadose water and dissolution at the water table. They also enhance piping and erosion, migration of unconsolidated deposits into karst cavities and washing-out of cavities, thus further enhancing the potential for subsidence.

When passing from deep-seated to the subjacent karst stage, artesian caves, both maze-like and large discrete voids, readily give rise to breakdown development. In the artesian maze systems of the Western Ukraine, breakdown structures are scattered throughout the passages. They were initiated predominantly at points where outlet cupolas/domes (the features through which upward discharge from the systems took place during the artesian stage) have revealed and exploited local zones of the lowest integrity within the immediately overlying bed and the entire overburden (Klimchouk and Andrejchuk, this volume). Because of the small size and gauging effect of such outlet features, and the multi-layer structure of the overburden, break- 
down columns propagate to the surface through many stages during extended time periods.

Large discrete voids can generate large and deep single-event collapses. This is exemplified by the collapse sinkholes common in the Zechstein gypsum of the South Harz gypsum karst, and by historically recent collapses generated by cavities in the gypsum bed within the Muschelkalk succession in the Stuttgart region, Germany (i.e. Eisinger Loch collapse formed in 1966). It is likely that smaller cavities of this type cause some of the subsidence hazards in the Ripon and Darlington areas of the UK.

In general, cavities of this type are probably the main trigger for the development of "vertical through structures" (VTS). This is a generic term suggested for typical phenomena of many deep-seated and subjacent gypsum karst regions of the world, commonly referred to as breccia pipes, collapse columns and "geological organs" (Klimchouk and Andrejchouk, 1996). They may reach a remarkable vertical extent, up to several hundred metres, by upward stoping across a multi-storey artesian system that includes soluble beds. VTS are not merely breakdown structures, but complex hydrogeologic structures whose development depends on focused cross-formational groundwater circulation and continuing dissolution of intercepted soluble beds and infallen clasts.

Entrenched karst is generally less prone to generate subsidence and related engineering problems than subjacent karst. This is because most of inherited cavities are stabilized with respect to the new conditions, the water table is commonly lowered below the bottom of a karst unit and contemporary dissolution is localized along a limited number of lateral flow paths or along the water table where it remains within gypsum. The entrenched karst zone in the Western Ukraine exemplifies this situation (see Klimchouk and Andrejchuk, this volume). The main speleogenetic triggers for breakdown development in entrenched karst are vertical solution pipes. They develop downward from a suitably protective bed at the top of gypsum (commonly limestone or dolomite), due to focused dissolution by groundwater that percolates through the overburden, or leaks from perched aquifers above the gypsum along prominent vertical discontinuities. Pipes 1 to $5 \mathrm{~m}$ wide cut across the whole gypsum stratum or down to the water table, commonly intersecting relict lateral passages. The density of vertical solution pipes can be high, for instance, up to 300 pipes per $\mathrm{km}^{2}$ at the Kungursky Cave area in the fore-Ural, Russia (see Andrejchuk and Klimchouk, this volume). Breakdown structures that initiate after the pipes are ready to propagate through the large thicknesses of the overburden because of involvement of hydrodynamic mechanisms in the breakdown processes and the presence of the discontinuity in the overlying stratum, which was instrumental in the development of the dissolution pipe in the first place.

Among other types, exhumed karst, and mantled karst may cause pronounced subsidence problems, particularly where the water table is positioned within a karst unit. Areas within the major river valleys in the Ebro Basin in Zaragoza region, Spain, exemplify the subsidence hazard associated with the alluviated subtype of mantled karst. 
Buried karst does not normally generate subsidence, as it commonly results from marine transgression. Thus it loses its hydrological function and becomes fossilized.

\section{Conclusion}

The evolutionary typology of karst can be used as the basis, or as an important initial step, for general regional assessment of subsidence hazards. The types of karst differ quite naturally in their styles of speleogenesis, karst breakdown settings and characteristic mechanisms of the breakdown formation. Therefore, subsidence hazards also differ substantially between the karst types, so that one can obtain a kind of integrated general assessment by classifying a given individual karst according to this typology. This provides a useful basis for the selection and realisation of regionand site-specific assessment schemes and management strategies.

Intrastratal karst types, subjacent karst in particular, are the most potent in generating subsidence problems. Exposed karst types, especially open karst, are the least likely to pose subsidence hazard despite the fact that they are more obviously recognised as karstic areas.

\section{Acknowledgement}

This study was partially supported by the ROSES (Risk of Subsidence due to Evaporite Solution) Project ENV4-CT97-0603 funded by the EC Framework IV Programme. Thanks to Dr.David J. Lowe for smoothing the English text,

\section{REFERENCES}

ANDREJCHUK V.N. 1999. Collapses above gypsum labyrinthic caves and stability assess ment of karstified terraines. Chernovtsy, Prut: $51 \mathrm{p}$ (russ.).

IVANOV B.N. 1956. On typology of karst landscapes of planes, on the example of Podol'skoBulovinsky karst region. In: Voprosy izuchenija karsta na juge Evropejskoj chasti SSSR. Yalta: 131-156 (russ.)

KEMPE S. 1996. Gypsum karst of Germany: 209-224. In: KLIMCHOUK A.B., LOWE D.J., COOPER A.H. and SAURO U. (Eds.) - Gypsum karst of the World. Int. Journal of Speleology Theme issue 25 (3-4).

KLIMCHOUK A.B. 1996. The typology of gypsum karst according to its geological and geo morphological evolution: 49-60. In: KLIMCHOUK A.B., LOWE D.J., COOPER A.H. and SAURO U. (Eds.) - Gypsum karst of the World. Int. Journal of Speleology Theme issue 25 (3-4).

KLIMCHOUK A.B. 1997a. Artesian speleogenetic settings. Proceedings of the 12th Int. Congr. of Speleol. vol.1 La Chaux-de-Fonds Switzerland 10-17.08.1997, 157-160

KLIMCHOUK A.B. 1997b. Speleogenetic effects of water density differences. Proceedings of the 12th Int. Congr. of Speleol. vol.1 La Chaux-de-Fonds Switzerland 1017.08.1997, 161-164 
KLIMCHOUK A.B. 2000a. Speleogenesis under deep-seated and confined settings: 244-260. In: KLIMCHOUK A., FORD D., PALMER A. and DREYBRODT W. (Eds.) Speleogenesis: Evolution of karst aquifers. Huntsville: Natl. Speleol. Soc.

KLIMCHOUK A.B. 2000b. Speleogenesis in gypsum: 431-442. In: KLIMCHOUK A., FORD D., PALMER A. and DREYBRODT W. (Eds.) - Speleogenesis: Evolution of karst aquifers. Huntsville: Natl. Speleol. Soc.

KLIMCHOUK A.B. \& AKSEM S.D. 2002. Gypsum karst in the Western Ukraine: hydro chemistry and solution rates. Carbonates and Evaporites 17 (2), 142-153.

KLIMCHOUK A.B. \& ANDREJCHUK V.N. 1996. Breakdown development in cover beds, and landscape features induced by intrastratal gypsum karst: 127-144. In: KLIMCHOUK A.B., LOWE D.J., COOPER A.H. and SAURO U. (Eds.) - Gypsum karst of the World. Int. Journal of Speleology Theme issue 25 (3-4).

KLIMCHOUK A.B. \& FORD D.C. 2000. Types of karst and evolution of hydrogeologic set tings: 45-53. In: KLIMCHOUK A., FORD D., PALMER A. and DREYBRODT W. (Eds.) - Speleogenesis: Evolution of karst aquifers. Huntsville: Natl. Speleol. Soc.

NEWTON J.G. 1984. Review of induced sinkhole development: 3-9. In: BACK B. (Ed) Sinkholes: Their Geology, Engineering and Environmental Impact. Proceedings of the First multidisciplinary conference on sinkholes, Orlando/Florida, 15-17 October 1984. Rotterdam/Boston: A.A.Balkema, 1984.

QUINLAN J.F. 1978. Types of karst, with emphasis on cover beds in their classification and development. PhD Thesis, Univ. of Texas at Austin.

WHITE E. \& WHITE W. 2000. Breakdown morphology: 427-429. In: KLIMCHOUK A., FORD D., PALMER A. and DREYBRODT W. (Eds.) - Speleogenesis: Evolution of karst aquifers. Huntsville: Natl. Speleol. Soc. 